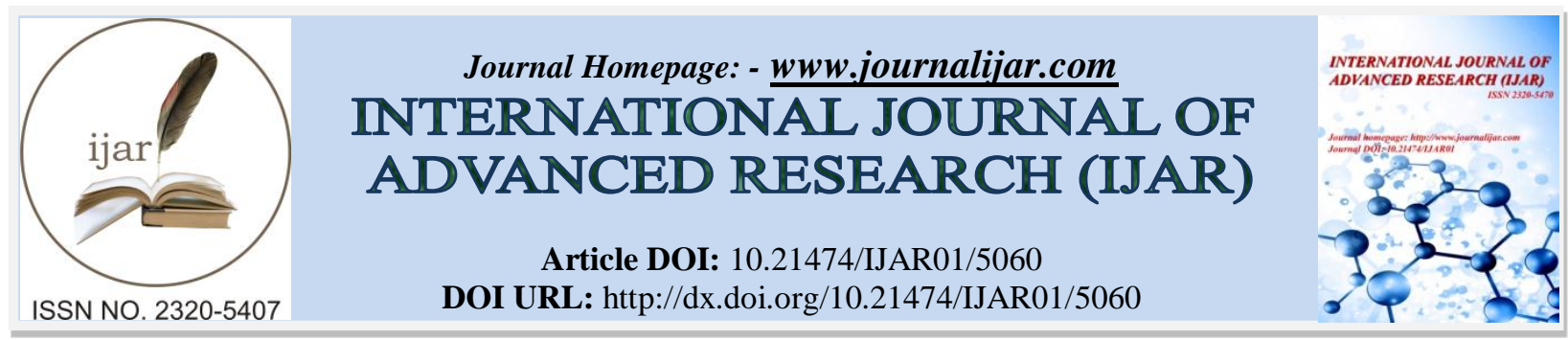

RESEARCH ARTICLE

\title{
A STUDY OF SCHOOL LEARNING CULTURE IN REFERENCE TO LEADERSHIP BEHAVIOR OF PRINCIPALS OF SECONDARY SCHOOLS.
}

\author{
Dr. Sumati Rani ${ }^{1}$ and Dr. Pramod Joshi ${ }^{2}$. \\ 1. Assistant Teacher, Department of Education, Government Girls Inter College, Parkham, Mathura. India. \\ 2. Assistant Professor, School of Education, Central University of Haryana, Haryana. India.
}

\section{Manuscript Info}

Manuscript History

Received: 03 June 2017

Final Accepted: 05 July 2017

Published: August 2017

Key words:-

Leadership Behavior, School Learning

Culture and Secondary Schools

\begin{abstract}
The main aim of this research was to study the school learning culture in reference to leadership behavior of principals. For fulfill the main aim of the study the researcher framed following objectives: to study the leadership behavior of principals and to study the school learning culture in relation to leadership behavior of principals. Descriptive survey method was employed and the present study was confined to the principals (20 male and 20 female) and 400 students of 40 secondary schools affiliated to U.P. Board of Education purposively. Leader Behavior Scale (LBS) developed by Dr. Asha Hinger was used for data collection. It helps in identifying various dimensions of leadership behavior in terms of effectiveness on the basis of self-perception. Mean. S.D. and C.R. Value were calculated to analysis the data. The result of the study concluded that gender differences do not exist in relation to leadership behavior of principals as both male and female principals are provided equal facilities. The leadership behaviour of school principals positively influences the school learning culture. School learning culture differ significantly in relation to the most, moderate and least effective leadership behavior of principals which implies that with the effective leadership decreasing strength the dependent variable.
\end{abstract}

Copy Right, IJAR, 2017,. All rights reserved.

\section{Introduction:-}

A school learning culture is one of the most difficult to describe and yet one of the most important elements in the success or failure in educating its students. The concept of school culture probably derives most immediately and directly from the oft-repeated observation; schools differ one from the other in the way they work as well as in the 'effects' that they have on the lives of children (Deal and Peterson, 1990, 1999; Sashkin and Walberg, 1993). Some schools are seen as better or worse than they are, some have "reputations," some are suffocating while others nurturing. Every school is perceived as different and every school has its own atmosphere and mood.

A principal is a designated leader of the school. He has the major responsibility of promoting his institution. But it is not possible for him to work in isolation; he needs the help of his staff - members. The relationship which a principal develops with his staff-members helps in the attainment of educational goals. The tone or the atmosphere of a school is determined to a large extent by the intelligence, personality, imagination, scholarship and initiative of the principal and his healthy interaction with his staff-members. Thus, the behavior of the principal has relationship

Corresponding Author:- Sumati Rani.

Address:- Assistant Teacher, Department of Education, Government Girls Inter College, Parkham, 
with the behavior of teachers, their morale, receptivity of innovative ideas and school practices. Therefore, it is the circular chain and if anything happens to anyone, the whole school system gets affected. It is in this context, that the present study has been made.

\section{Review of Related Literature:-}

The brief account of the previous researches is presented as:

Zaid and Vali (2016) studied leaderships behavior and its relation with principals' management, Roghaiyeh, S.S. \& Pravenna, K.B. (2013) conducted a study on influence of gender and type of school on leadership behavior among school teachers, Sharma, S., Sun, H. and Kannan, S. (2012) studied a comparative analysis of leadership qualities of school principals in China, Malaysia and India, Martin, T.R. (2011) examined the relationship between principal leadership behavior and principal experience, Lyons, B.J. (2010) explore the study on principal instructional leadership behavior as perceived by teachers and principals, at New York state recognized and non-recognized Middle Schools, Sancar, M. (2009) conducted a study on leadership behaviors of school principals in relation to teacher job-satisfaction and Davitt, S. J.(2008) examined an exploratory study of principal innovativeness and leadership behavior.

Researches shows quite clearly that schools perceived as being positive, safe, nurturing and focused on student learning do better than schools that lack this type of school learning culture regardless of say available technology, teacher training and other more obvious factors. This is not to say that a school with no textbooks will outperform one with textbooks based solely on environment, but that the learning culture produced by the school as a whole can help or hinder in dramatic ways. Like the larger social culture, a school learning culture results from both conscious and unconscious perspectives, values, interactions, and practices, and it is heavily shaped by a school's particular institutional history. Students, parents, teachers, administrators, and other staff members all contribute to their school's learning culture, as do other influences such as the community in which the school is located, the policies that govern how it operates, or the principles upon which the school was founded.

\section{Objectives of the Study:-}

1. To study the leadership behavior of the male and female principals.

2. To study the school learning culture in relation to leadership behavior of principals.

\section{Methodology:-}

Method of the Study:

The researcher has adopted descriptive survey method for the present study.

\section{Sample Selection:}

The present study was confined to the principals (20 male and 20 female) and 400 students of 40 secondary schools affiliated to U.P. Board of Education. The purposively method of the sampling was used in selection of the sample of the study.

Tools \& Techniques of Data Collection: Leader Behavior Scale (LBS) developed by Dr. Asha Hinger was used for data collection. It helps in identifying various dimensions of leadership behavior in terms of effectiveness on the basis of self-perception.

\section{Statistical techniques used:}

Mean. S.D. and t- Value were calculated to analysis the data.

\section{Result and Discussion:-}

The data collected is tabulated and the results obtained are presented under the following headings:

\section{To Study Leadership Behavior of Male and Female Principals}

The researcher analysis the data in order to study the leadership behavior of male and female principals, values of Mean and standard deviation have been calculated and to study the gender difference in leadership behavior, $t$-value has been obtained and given in the table 1 . 
Table-1:- Showing Mean, S.D. \& t-value for Leadership Behavior of Male and Female Principals

\begin{tabular}{|l|l|l|l|l|l|l|l|}
\hline \multirow{2}{*}{$\begin{array}{l}\text { Leadership } \\
\text { Behavior }\end{array}$} & Gender & $\mathrm{N}$ & Mean & S.D. & t-value & df & $\begin{array}{l}\text { Level of } \\
\text { significance }\end{array}$ \\
\cline { 2 - 8 } & Male & $\mathbf{2 0}$ & $\mathbf{1 1 8 . 8 4}$ & $\mathbf{1 3 . 4 2}$ & $\mathbf{0 . 6 6}$ & $\mathbf{3 9}$ & $\begin{array}{l}\text { Not significant } \\
\text { at 0.05 level }\end{array}$ \\
\cline { 2 - 8 } & Female & $\mathbf{2 0}$ & $\mathbf{1 1 6 . 1 1}$ & $\mathbf{1 2 . 9 6}$ & & & \\
\hline
\end{tabular}

From the above table, it is inferred that mean values of leadership behavior for male and female principals are 118.84 and 116.11 respectively and related value of standard deviation are 13.42 and 12.96 respectively. The calculated t-value between male and female principals regarding their leadership behavior has been found 0.66 which is less than table value at 39 degree of freedom on 0.05 level of confidence. Hence, it can be said that there exists no significant difference between leadership behavior of male and female principals or in other words it can be said that gender has no effect on leadership behavior of principals. This may be due to the reason that leadership behavior upto some extent depends on the environmental exposure or situations available.

To Study the School Learning Culture in reference to the Leadership Behavior (Most, Moderate and Least Effective) of their Principals

The researcher analyzed the data of school learning culture separately from the schools having their principals with most, moderate and least effective leadership behavior for studying the school learning culture with reference to leadership behavior of their school principals,. The researcher calculated mean values, standard deviation and $\mathrm{t}$ value for school learning culture through students' perception in relation to leadership behavior of their school principals which are shown in the table 2-

Table 2:- Showing Mean, S.D. \& t-value for School Learning Culture in reference to Different Categories of Leadership Behavior Effectiveness

\begin{tabular}{|c|c|c|c|c|c|}
\hline \multirow[t]{2}{*}{ LB Effectiveness } & \multicolumn{3}{|c|}{ School learning culture (SLC) } & \multirow[t]{2}{*}{ t-value } & \multirow{2}{*}{$\begin{array}{l}\text { Level } \\
\text { significance }\end{array}$} \\
\hline & $\mathbf{N}$ & M & S.D. & & \\
\hline $\begin{array}{l}\text { Most } \\
\text { Moderate }\end{array}$ & $\begin{array}{l}125 \\
165\end{array}$ & $\begin{array}{l}131.72 \\
124.45\end{array}$ & $\begin{array}{l}3.92 \\
8.66\end{array}$ & 6.92 & Significant at 0.01 \\
\hline $\begin{array}{l}\text { Moderate } \\
\text { Least }\end{array}$ & $\begin{array}{l}165 \\
110\end{array}$ & $\begin{array}{l}124.45 \\
118.54\end{array}$ & $\begin{array}{l}8.66 \\
4.87\end{array}$ & 7.14 & Significant at 0.01 \\
\hline $\begin{array}{l}\text { Most } \\
\text { Least }\end{array}$ & $\begin{array}{l}125 \\
110\end{array}$ & \begin{tabular}{|l|}
131.72 \\
118.54
\end{tabular} & $\begin{array}{l}3.92 \\
4.87\end{array}$ & 19.36 & Significant at 0.01 \\
\hline
\end{tabular}

It is inferred from the table 2 that the mean values of school learning culture having principals with most, moderate and least effective leadership behavior are 131.72, 124.45 and 118.54 respectively and their respective values of standard deviation are 3.92, 8.66 and 4.87. It is further revealed that the mean values of school learning culture were found highest with most effective leadership behavior and gradually decreases in case of moderate and least effective leadership behavior of their principals which clearly indicates that the mean of the school learning culture having principals with most effective leadership behavior is more than of those schools having principals with moderate and least effective leadership behavior. In simple words, it can be inferred that the schools having most effective principals are found to have highest mean values of school learning culture and the values decreased with the decreased effectiveness of principals.

\section{Conclusion of the Study:-}

The result of the present study concludes that gender differences do not exist in relation to leadership behavior of principals as both male and female principals are provided equal facilities and other incentives and are exposed to similar kind of organizational atmosphere getting almost similar stimuli to respond hence they do not differ in their leadership behavior. The leadership behaviour of school principals positively influences the school learning culture. School learning culture differ significantly in relation to the most, moderate and least effective leadership behavior of principals which implies that with the effective leadership decreasing strength the dependent variable. 


\section{References:-}

1. Davitt, S. J. (2008). An Exploratory Study of Principal Innovativeness and Leadership Behavior, (Doctoral dissertation). Retrieved from: https:// scholarsbank.uoregon.edu/.../Davit...

2. Deal, T. E. \& Peterson, K .D. (1990). The Principal's Role in Shaping School Culture.Washington:DC. Office of Educational Research and Improvement.

3. Dubey, Akanksha (2016). Leadership Behavior of Principals as the Predictor of School Learning Culture, Students' Achievement and Some of the Characteristics of Teachers. http.www.shodhganga.com.

4. Lyons, B.J. (2010). Principal Instructional Leadership Behavior as Perceived by Teachers and Principals, at New York State Recognized and Non-Recognized Middle Schools. (Doctoral dissertation, Seton Hall University). Retrieved from: http://scholarship . shu.edu /dissertations /1401

5. Martin, T.R. (2011). The Relationship between Principal Leadership Behavior and Principal Experience. Retrieved from: ProQuest Dissertations and Theses.

6. Roghaiyeh, S.S. \& Pravenna, K.B. (2013). Influence of Gender and Type of School on Leadership Behavior among School Teachers. Paripex - Indian Journal of Research, 2(8).

7. Sancar, M. (2009). Leadership Behaviors of School Principals in relation to Teacher Job-Satisfaction. A Paper presented at World Conference on Educational Sciences, Faculty of Education, Department of Educational Sciences, Eastern Mediterranean University, Famagusta-NorthCyprus.

8. Sharma, S., Sun, H. \& Kannan, S. (2012). A Comparative Analysis of Leadership Qualities of School Principals in China, Malaysia \& India. International Online Journal of Educational Sciences, 4(3), 536-543. Retrieved from: www.iojes.net/userfiles/.../IOJES_862.pdf

9. Zaid and Vali (2016). Leaderships Behavior and Its Relation with Principals' Management, New Approaches in Educational Research, Vol.5 No.1 